\section{Contaminated cell lines}

\section{from David Dickson, Washington}

YET another corruption of the scientific literature has been uncovered with the discovery that several cell lines widely quoted in the scientific literature as originating from patients with Hodgkin's disease have now been shown not to be human cells at all, but to come from a strain of owl monkey (see the accompanying article, pages 228-230).

The cells were grown in culture by $\mathrm{Dr}$ John C. Long, who resigned a year ago as assistant pathologist at the Massachusetts General Hospital and associate professor of pathology at Harvard Medical School, after admitting to having faked data in a research paper published in the Journal of the National Cancer Institute in 1979.

On resigning Dr Long admitted having misled colleagues about carrying out experiments to produce revised data on the molecular weights of immune complexes. The alterations were included in the paper after it had been rejected by the referees of another journal.

Dr Long said on the telephone last week that during his time at the Massachusetts General Hospital, he had no reason to suspect that his cell lines were contaminated and welcomed the work of Harris et al. However, when he resigned, he did not reveal that six months earlier he had received data from the National Cancer Institute (NCI) casting doubt on the identity of the cells.

The first successful long-term cultivation of cells from patients with Hodgkin's disease was claimed by Dr Long and colleagues from the hospital and the medical school in Proceedings of the National Academy of Sciences (PNAS) in 1973. Other groups have encountered considerable difficulty in establishing permanent lines from diseased spleen cells.

The procedures used to grow the original cells through over 200 passages were described in a 1977 paper in Journal of Experimental Medicine as well as PNAS. (Science Citation Index lists 30 citations of this paper in 1979 and 1980 , which its compilers say means the paper is "highly cited".) In total four papers have appeared in $P N A S$ - three naming Dr Long as the first author. Experiments using these cells have also been described in other publications (see page 228 ).

All the papers referring directly to the now-challenged cell cultures will have to be reassessed to see if any data of scientific value can be salvaged, since there is now evidence that the cell lines were contaminated from an early stage.

Dr Long was awarded a three-year grant for more than $\$ 200,000$ in 1976 to continue his study of the Hodgkin's disease tissue cultures. This was renewed in 1979 - based on an application said to include the data which he later admitted forging - and he received $\$ 96,000$ in that year, as the first part of a three-year grant of almost $\$ 500,000$.

This grant was terminated by the NCI at the request of the hospital, after Dr Long admitted falsifying data in the 1979 paper in Journal of the National Cancer Institute. According to the hospital, Dr Long claimed at the time that "competition for federal research grants" was a major factor in causing him to lie about experiments he had not carried out.

However, he did not admit to any other impropriety and the hospital put out a statement saying that the data he had admitted falsifying was "obscure, and of no known significance. . . no known harm has resulted even in the field of science".

The hospital also said that further suspicions about his research were being followed up. There was already evidence of contamination of the cell lines - early in 1979 one of Dr Long's research associates had grown suspicious about the true nature of the cells, and sent samples to Dr Stephen O'Brien at the NCI Laboratory of Viral Carcinogenesis for genotypic evaluation.

The NCI scientists told Dr Long that three of the cell lines carried the enzymatic signature of the same individual. And they also pointed out an unusual characteristic they could not explain - a peculiarly fast mobility in a key enzyme system.

Dr Long did not follow up this comment with the NCI. And he told his research workers that the NCI check had shown that the cells were genuine - indeed that in one case the signature of the cultured cells corresponded directly with that of the red blood cells of the patient from whom the cells were said to have been taken (another claim subsequently shown to be false).

Nothing further happened at the time. But after Dr Long's resignation, Dr Robert T. McCluskey, head of the hospital's pathology department, considered further investigations necessary. Karyotypes and cell samples were sent to the cell culture laboratory at the University of California's School of Public Health, where chromosomal analysis revealed that the cells were not human. Several other laboratories were subsequently sent samples to complete the identification. And the karyotype was recognized as that of the owl monkey by Dr Bharati Hukku of the Child Research Center of Michigan, Detroit.

The cells were then confirmed by the New England Regional Primate Center as coming from a Northern Columbian brown foot owl monkey. Indirect evidence that this was the likely source of contamination was the fact that this cell line had been used for virus research in the early 1970 s in the laboratory in which Dr Long was then working.
The fourth suspected cell line, started later than the other three, has turned out to be human. But there is no evidence of a link with Hodgkin's disease tumours.

The full impact of Dr Long's publications remains unclear. His results have been quoted as supporting a particular view of the pathogenesis of Hodgkin's disease which may now be questioned, in particular suggesting a macrophage origin of the peculiarly large Reed-Sternberg cells found in Hodgkin's patients.

Other research workers have been careful not to put too much weight on $\mathrm{Dr}$ Long's results, remaining sceptical in the light of their own failure to culture the same cells. And Dr Henry Kaplan of Stanford University feels that the main impact may have been to reduce the incentive for others to tackle the problem of growing the cells in vitro, since Dr Long had already claimed success.

Investigators for the Department of Health and Human Services in Boston must now decide whether there is any evidence that should be passed to the Department of Justice to charge Dr Long with fraud against the federal government. Under the US Code, consciously providing false information when applying for federal assistance is a criminal of fence.

The journals which published Dr Long's papers now have to decide what action to take. A representative of the National Academy of Sciences has said that the situation was "unique" for $P N A S$, which has never previously had to disown any paper it has published.

Papers submitted to PNAS are not formally reviewed if a member of the academy is a co-author. In Dr Long's case, each of the four papers that he published was written with academy member Dr Paul Zamecnik, who recently retired as professor of oncological medicine and director of the J.C. Warren Laboratories at Harvard Medical School, where Dr Long was a research student.

The National Institutes of Health are already discussing how to tighten up on evaluating the scientific content of research funded by federal grants. An audit of Dr Long's grant revealed no fiscal irregularities in the way that the money had been used, but did not go into the legitimacy of the research.

Ironically, the recently created President's Commission for the Study of Ethical Problems in Medicine and Biomedical and Behavioral Research is now considering another Boston case, in which a research worker at the Boston University Medical School was shown to have faked data in a cancer survey.

Research administrators admit that cases of fraud - usually relatively minor - are not unusual, although few reach the public eye. "Whatever you see is probably only a small fraction of what actually goes on," according to Dr Donald Kennedy, president of Stanford University. 